\title{
Inequality of opportunity in an outermost region: the case of the Canary Islands
}

\section{Moises Betancort}

Universidad de La Laguna (ULL), Canary Islands, Spain

Centro de Estudios de Desigualdad Social y Gobernanza (CEDESOG), ULL, Spain moibemo@ull.edu.es

\section{Sara Darias-Curvo}

Universidad de La Laguna (ULL), Canary Islands, Spain

Centro de Estudios de Desigualdad Social y Gobernanza (CEDESOG), ULL, Spain sadacur@ull.edu.es

\section{Leopoldo Cabrera}

Universidad de La Laguna (ULL), Canary Islands, Spain

Centro de Estudios de Desigualdad Social y Gobernanza (CEDESOG), ULL, Spain lcabre@ull.edu.es

\section{Gustavo A. Marrero}

Universidad de La Laguna (ULL), Canary Islands, Spain

Centro de Estudios de Desigualdad Social y Gobernanza (CEDESOG), ULL, Spain EQUALITAS, Spain

gmarrero@ull.es (corresponding author)

\section{Carmen Nieves Pérez}

Universidad de La Laguna (ULL), Canary Islands, Spain

Centro de Estudios de Desigualdad Social y Gobernanza (CEDESOG), ULL, Spain cperez@ull.edu.es

\section{Juan Gabriel Rodríguez}

Centro de Estudios de Desigualdad Social y Gobernanza (CEDESOG), ULL, Spain EQUALITAS, Spain

Universidad Complutense de Madrid, Spain

juangabr@ucm.es

\section{Daniel Sánchez}

Universidad de La Laguna (ULL), Canary Islands, Spain

Centro de Estudios de Desigualdad Social y Gobernanza (CEDESOG), ULL, Spain danisr993@gmail.com 
Abstract: This article estimates the inequality of opportunity (IO) for the Canary Islands archipelago, a European outermost region of seven islands, including two capital islands and five peripheral islands. To achieve this goal, a survey has been designed to cover a wide range of circumstances, including type of household, socioeconomic background, health status, type of school, family environment, and instilled values during childhood. This new database is one of the main contributions of the paper. For all of the Canary Islands, IO represents approximately $12.4 \%$ of total inequality, which is in line with the values found for the South European countries in related studies. However, when we distinguish by type of island, the IO in the peripheral islands accounts for almost $20 \%$ of total inequality, which is more in line with Latin American economies. This difference may affect the origin of significant migration flows from the peripheral to the capital islands and future divergence in their development.

Keywords: Canary Islands, development, inequality of opportunity, migration flows, outermost region

https://doi.org/10.24043/isj.88 • Received March 2018, accepted March 2019

(C) 2019-Institute of Island Studies, University of Prince Edward Island, Canada.

\section{Introduction}

Located in the Atlantic Ocean, about $100 \mathrm{~km}$ off the northwest coast of Africa, and approximately $940 \mathrm{~km}$ southwest of mainland Spain, the Canary Islands archipelago is one of 17 autonomous regions in Spain, and one of the European Union's nine recognized outermost regions (European Commission, 2018). The archipelago is composed of seven islands of volcanic origin, administratively split into two provinces: Tenerife (the capital), La Palma, La Gomera, and El Hierro comprise the western province (Santa Cruz de Tenerife); whereas Gran Canaria (the capital), Fuerteventura, and Lanzarote constitute the eastern province (Las Palmas de Gran Canaria). Tenerife and Gran Canaria are the two capitals of the province and the most populous islands with almost 900,000 inhabitants each $(80 \%$ of total population); Lanzarote and Fuerteventura are medium-sized, with populations of over 100,000 inhabitants; finally, the smallest islands are La Palma with about 88,000 inhabitants, and La Gomera and El Hierro, with less than 25,000 inhabitants each.

In terms of connectivity, the islands have good connections with mainland Spain and overseas, both by sea (12 commercial ports and 9 passenger ports) and air ( 8 airports, one per island, with the exception of Tenerife, where there are two). Despite all this, because of their isolation from the continent, distances and differences among islands, and their condition of isolated electric system (Marrero \& Ramos-Real, 2010), the archipelago has its own Economic and Fiscal Regime (REF, Law 19/1994) and is categorized as a free port to compensate for derivative costs.

Their outermost region status makes the Canary Islands a significant case for the study of the Inequality of Opportunity (IO) because, although institutions in the archipelago are comparable to those in the rest of Spain, the islands have an income per inhabitant that is $82 \%$ 
of that in Spain (Instituto Canario de Estadística, 2018a), nearly the highest rates of unemployment (21.9\%), youth unemployment (40.9\%), long-term unemployment $(38.1 \%)$, school dropout (16.5\%) and relative poverty (35\%) according to Instituto Nacional de Estadística (2017a), and the highest rate of population at risk of social exclusion in the entire country, with an AROPE index of 44.6\% in 2016 (Instituto Nacional de Estadística, 2017b).

Conditions in the archipelago may also be affecting opportunities for its population, especially economic opportunities for the inhabitants of the smallest and most remote islands, where nepotism and absence of meritocracy have a priori more opportunity to develop (Armstrong et al., 2012; Gjinovci, 2016; Rodriguez-Pose \& Garcilazo 2015).

According to the IO literature, an individual's outcome (income, wealth, or health) is the result of interaction between effort variables (like number of hours worked and occupational choice) and circumstances (for example, socioeconomic background, race, or sex). However, individuals are only in part responsible for their situation, with circumstances beyond the individual's control also having an impact. In this literature, IO refers to the inequality that is due to individuals' circumstances and not to effort (Roemer, 1993, 1998). According to this literature, society should compensate individuals who suffer from bad circumstances while allowing individuals to exercise their responsibility without trying to distort their outcomes (Fleurbaey, 2008; Roemer \& Trannoy, 2016). A new and interesting aspect of IO is that, beyond its consideration as unfair inequality from an ethical point of view, it seems to have a negative effect on subsequent economic growth (Bradbury \& Triest, 2016; Marrero \& Rodríguez, 2013; Marrero et al., 2016). Reducing the IO of a region or country would thus not only improve social justice, but also the degree of efficiency of the region.

One of the main contributions of this article is to create a new database, compiled by the authors and including a large number of circumstances, to estimate the IO in an outermost region, taking the Canary Islands as our case study. We are interested in evaluating if the conditions of insularity and geographical isolation have an effect on the level of opportunities for the inhabitants of that region, despite belonging to one of the most developed areas in the world (EU). In this respect, it is worth noting that the islands have similar institutional structures yet internal socioeconomic differences, especially between the two capitals (Tenerife and Gran Canaria) and the most peripheral islands (Lanzarote and Fuerteventura in the eastern part, close to the African continent, and La Palma, La Gomera, and El Hierro in the western part, located farther into the Atlantic). Significant differences of inequality and IO among the islands in the archipelago could imply divergent developments between the two capitals and the rest of the islands.

In this research, we use a new survey expressly conducted for the study of the IO in the Canary Islands in 2016. It contains information about the individuals' income, education, and occupation, and includes a wide range of circumstances relating to the type of birth household, parental socioeconomic status, health status during childhood, and values instilled by parents during childhood. As far as we are aware, this is the first database that allows measurement and analysis of IO in an isolated area like the Canary Islands archipelago.

Among the alternative methods of estimating IO (see Ramos \& Van de Gaer, 2017), we use the ex-ante and parametric approach proposed by Ferreira and Guignoux (2011), since it allows us to take full advantage of the high number of circumstances in our database and compare the estimates with previous results for Spain and Europe (Marrero \& Rodríguez, 2012). We base our estimates of IO on the Mean Logarithmic Deviation (MLD) inequality 
index and, for illustrative reasons, we also consider the Theil and Gini indexes (Brunori et al., 2016). This analysis is carried out on different models according to the type of circumstances considered and for certain relevant groups of islands.

In the following section, a summary of the survey is presented and the selected sample is documented. In addition, a brief descriptive analysis of the main variables used in the IO analysis in the Canary Islands is presented. The next section estimates and analyses IO in the archipelago as a whole, by groups of islands, and for the different models established according to the set of circumstances considered. The final section shows the main conclusions of the study.

\section{A new database to estimate $I O$ in the Canary Islands: description and preliminary results}

This section describes the 'Survey on Inequality of Opportunity in the Canary Islands' (SIOC) carried out in the last trimester of 2015 and beginning of 2016, which is the first database expressly created to measure IO in the Canary Islands.

\section{The database and circumstances}

The SIOC is a new database, unique at the level of islands and isolated regions, which contains a wide set of relevant circumstances (see Marrero et al., 2017, for details). In accordance with the literature on IO, the age range considered in the SIOC is from 25 to 55 years of age. Thus, it intends to capture the income level of individuals during their most productive vital years and with their most stable income. Nevertheless, as we will see below, this pattern may differ in the case of the Canary Islands.

Focusing on the population of the archipelago between 25 and 55 years old, a simple random sample is conducted through a Computer Assisted Telephone Interview (CATI). This strategy allows the extraction of information from each island with different levels of error and, once the samples are weighed, obtain representative information for the entire population of the Canary Islands. The survey was conducted between November 2015 and February 2016. The initial sample comprises 1,993 individuals for the whole archipelago, with an approximate sampling error of $\pm 2.2 \%$.

Information has been gathered on three types of variables: first, a set of common variables in surveys, such as age, family structure, or place of residence of the individual; second, income (net), highest level of education achieved, and occupation; finally, a wide range of circumstances (Table 1). The large number of circumstances considered in the survey is a contribution of this work.

The circumstances considered can be classified into three groups according to their nature. First, 'basic circumstances': here we find gender, place of birth (in or out of the islands), structure of household in which the individual grew up (single parent, two parent, or two-parent extended), and health perception during adolescence (healthy or unhealthy). Second, 'socioeconomic circumstances', measured through the type of school where the participant studied (public/private), and the education level and occupational status of their parents. Finally, 'perception circumstances', a set of perception variables relating to 'family and school environment' during adolescence. This environment would be reflected by the individual's perception of their parents reading frequently at home, if parents instilled values like honesty and the culture 
of effort, if parents devoted resources to her education, and perception of the 'environment at school', based on memories of teachers encouraging a good study environment.

Table 1: Set of individual circumstances.

\section{Variable (encoding)}

\begin{tabular}{|ll|}
\hline GENDER $\left(\right.$ gender $\left._{i}\right)$ & Gender of individual: (1) Female; (0) Male. \\
\hline PLACE OF BIRTH $\left(\right.$ Place $\left._{i}\right)$ & $\begin{array}{l}\text { Place of birth of the individual: (0) 'Canary } \\
\text { Islands, same island as residence'; (1) 'Canary } \\
\text { Islands, another island'; (2) 'Mainland'; (3) 'Abroad'. }\end{array}$ \\
\hline HOUSEHOLD $\left(\right.$ Home $\left._{i}\right)$ & $\begin{array}{l}\text { Type of household where individual lived during } \\
\text { childhood: (0) 'Nuclear'; (1) 'One-parent'; (2) } \\
\text { 'Nuclear extended'. }\end{array}$ \\
\hline $\begin{array}{l}\text { HEALTH STATUS IN CHILDHOOD } \\
\left(\text { HealthInf }_{i}\right)\end{array}$ & $\begin{array}{l}\text { Health status of individual during childhood: (0) } \\
\text { 'Unhealthy'; (1) 'Healthy'. }\end{array}$ \\
\hline
\end{tabular}

EDUCATION OF FATHER/MOTHER Highest education level reached by father/mother: $\left(E_{\text {duFath }} ;\right.$ EduMoth $\left._{i}\right) \quad$ (0) 'Primary'; (1) 'Secondary'; (2) 'Further/Higher'.

OCCUPATIONAL STATUS OF Highest occupational status between both parents FATHER/MOTHER $\left(\right.$ StatusFath $_{i} ;$ StatusMoth $\left._{i}\right)$

\begin{tabular}{|c|c|}
\hline SCHOOL $\left(\right.$ School $\left._{i}\right)$ & $\begin{array}{l}\text { Type of school attended by individual during } \\
\text { childhood: (0) 'Public'; (1) 'Private or semi- } \\
\text { private'. }\end{array}$ \\
\hline $\begin{array}{l}\text { REMEMBERS PARENTS READ } \\
\left(\text { PRead }_{i}\right)\end{array}$ & $\begin{array}{l}\text { Remembers their parents read: (0) 'Other than } \\
\text { little-nothing'; (1) 'Little-nothing'. }\end{array}$ \\
\hline $\begin{array}{l}\text { REMEMBERS PARENTS INSTILLED } \\
\text { VALUES }\left(\text { PEffort }_{i}\right)\end{array}$ & $\begin{array}{l}\text { Remembers their parents instilled values of effort, } \\
\text { honesty, etc.: (0) 'Other than little-nothing'; (1) } \\
\text { 'Little-nothing'. }\end{array}$ \\
\hline $\begin{array}{l}\text { FAMILY DEVOTED RESOURCES TO } \\
\text { IMPROVING HER EDUCATION } \\
\left(\text { PResources }_{i}\right)\end{array}$ & $\begin{array}{l}\text { Remember their parents devoted resources to } \\
\text { improve his/her education (helped with } \\
\text { homework, private lessons, etc.): (0) 'Other than } \\
\text { little-nothing'; (1) 'Little-nothing'. }\end{array}$ \\
\hline $\begin{array}{l}\text { ENVIRONMENT OF STUDY } \\
\text { ENCOURAGED BY TEACHERS } \\
\left(\text { ETeacher }_{i}\right)\end{array}$ & $\begin{array}{l}\text { Remember at his/her school, teachers, in general, } \\
\text { encouraged a good environment of study } \\
\text { (exigency, effort was valued, etc.): (0) 'Other than } \\
\text { little-nothing'; (1) 'Little-nothing'. }\end{array}$ \\
\hline
\end{tabular}

The information concerning education levels reached by the individuals and their parents is based on UNESCO's International Standard Classification of Education (ISCED) (UNESCO, 2012), distinguishing three categories: primary, secondary, and further or higher education. Moreover, when categorizing the population according to the type of occupation, we utilise ISCO-08 (International 
Standardized Classification of Occupation), following the adjustment suggestions by the Spanish Centro de Investigaciones Sociológicas (CIS). Thus, the professional category is used to give a proxy for the occupational status or social class of the individual, distinguishing among lower, middle, and upper class. Lower class refers to non-qualified workers, qualified workers in farming and fishing, qualified workers in the construction industry, qualified workers in industry/mechanics, and labourers. Middle class refers to administrative staff, hotel and catering workers, personal services and security workers, shop assistants, drivers and mobile machinery operators, armed forces and police. Upper class refers to directors, managers and businesspeople, professionals and technicians, professional and technical assistants.

\section{The sample and data description}

Following the related literature, from the original sample (1,993 individuals), we exclude from the analysis those individuals who state that they have zero income $(13.4 \%$ from the original sample), or have no income at all (25.1\% from the original sample). A person with zero income is active but, at the moment of the interview, he/she is not receiving any salary. However, a person with "no income" is, in general, a inactive person, such as a student, a homemaker, etc. Thus, although they are different categories, they affect in the same way in the estimation of the IO. The survey also allows stating income by intervals. In order to have the maximum number of observations, individuals stating their income by interval are assigned the median of the said interval. By applying this procedure, we go from 1,065 observations (798 if zeros are excluded) to a total of 1,493 (1,226 if null values are excluded). The non-income group consists of unemployed people (68.9\%), students $(13.8 \%)$, homemakers $(10.5 \%)$, retirees and rentiers $(1.1 \%)$, and individuals in another undeclared work situation and others (5.7\%).

Bearing in mind these compositional aspects, and once the non-income individuals or those who gave an invalid response ('does not know, does not answer') have been excluded, the final sample of individuals between 25 and 55 years of age comprises 1,226 people. This is a large number of observations relative to the size of the region and compared to the samples frequently utilized in similar studies. For this refined sample, the average income is $€ 10,313$ net per year and per person. 


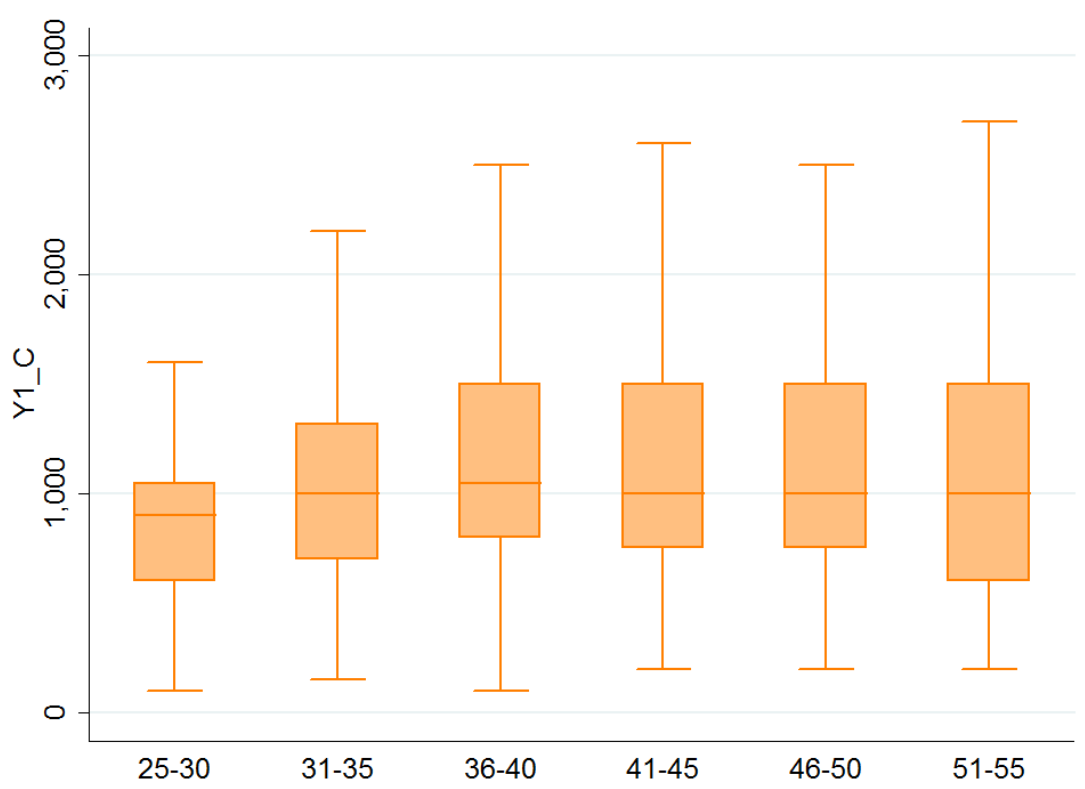

Figure 1: Individual's net monthly income in Canary Islands (by age).

Figure 2 shows the distribution of total individual income by deciles. It is observed that the $30 \%$ with the highest income gather $50 \%$ of the total income in the Canary Islands. Paying attention to the tails of the income distribution, the top decile (with a net monthly income above $€ 2,100$ ) acquires approximately seven times more income than the first income decile (with a net monthly income equivalent to €450). Ayala (2016), using data from the Spanish Family Budget Survey, suggests an income distribution for Spain in 2014 very similar to that for the Canary Islands. Thus, for the Canary Islands, the distance between the ninth and first deciles $\left(\mathrm{p}_{90} / \mathrm{p}_{10}\right)$ is 4.44 , if we take the individual net monthly income, whereas for Spain it is 4.34 . If we take the distance between the ninth decile and the mean $\left(\mathrm{p}_{90} / \mathrm{p}_{50}\right)$, the distance is again slightly higher for the Canary Islands (2.00) than for Spain (1.97).

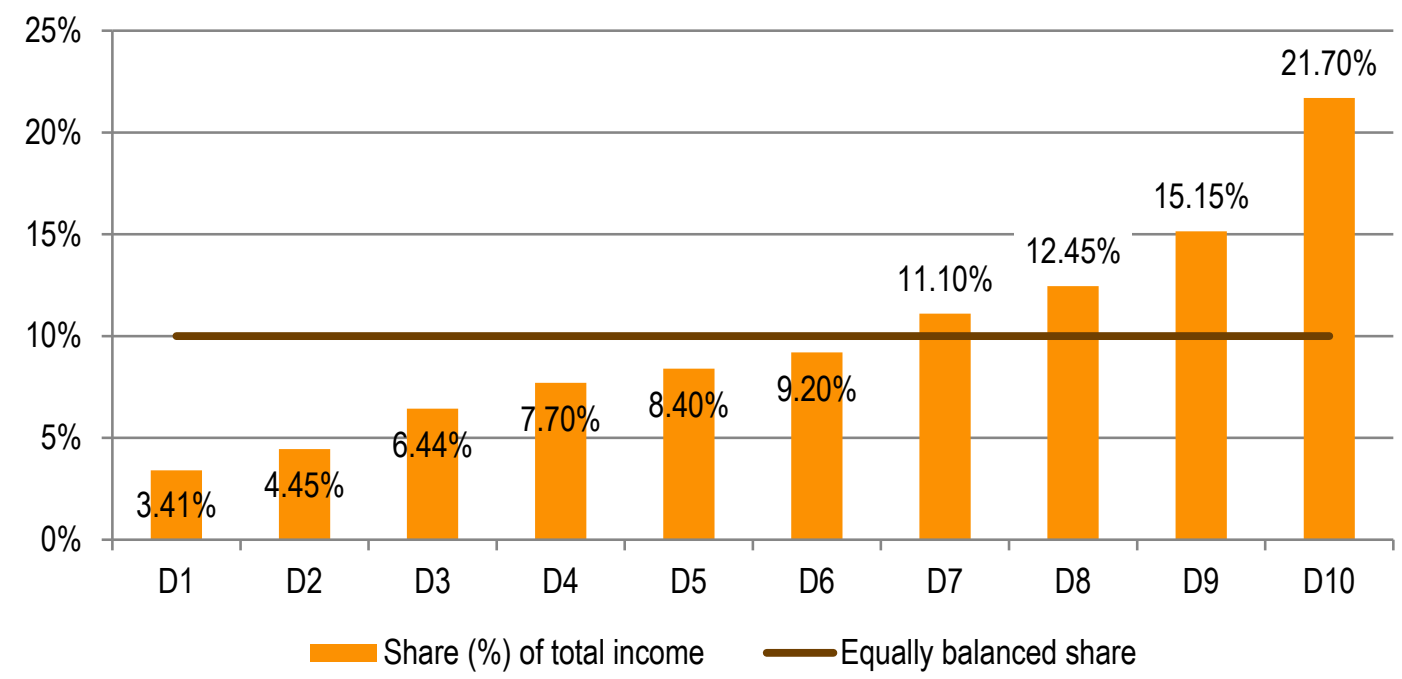

Figure 2: Individual's net income distribution in Canary Islands (by deciles). 
For our sample of individuals of between 25 and 55 years of age, the estimated Gini index for the Canary Islands is 0.313 (with 95\% confidence, the value of the coefficient is between 0.293 and 0.332). This value is slightly lower than those published by the official sources. According to data from the Encuesta de Ingresos y Condiciones de Vida de los Hogares Canarios (EICV-HC), designed by the Instituto Canario de Estadística, Gini index in the Canary Islands has gone from 0.290 in 2007 (lower than Spanish average) to 0.340 in 2013 (higher than Spanish average). In the next section, we compare the inequality estimations for the Canary Islands to those obtained for the set of capital islands and the more peripheral ones.
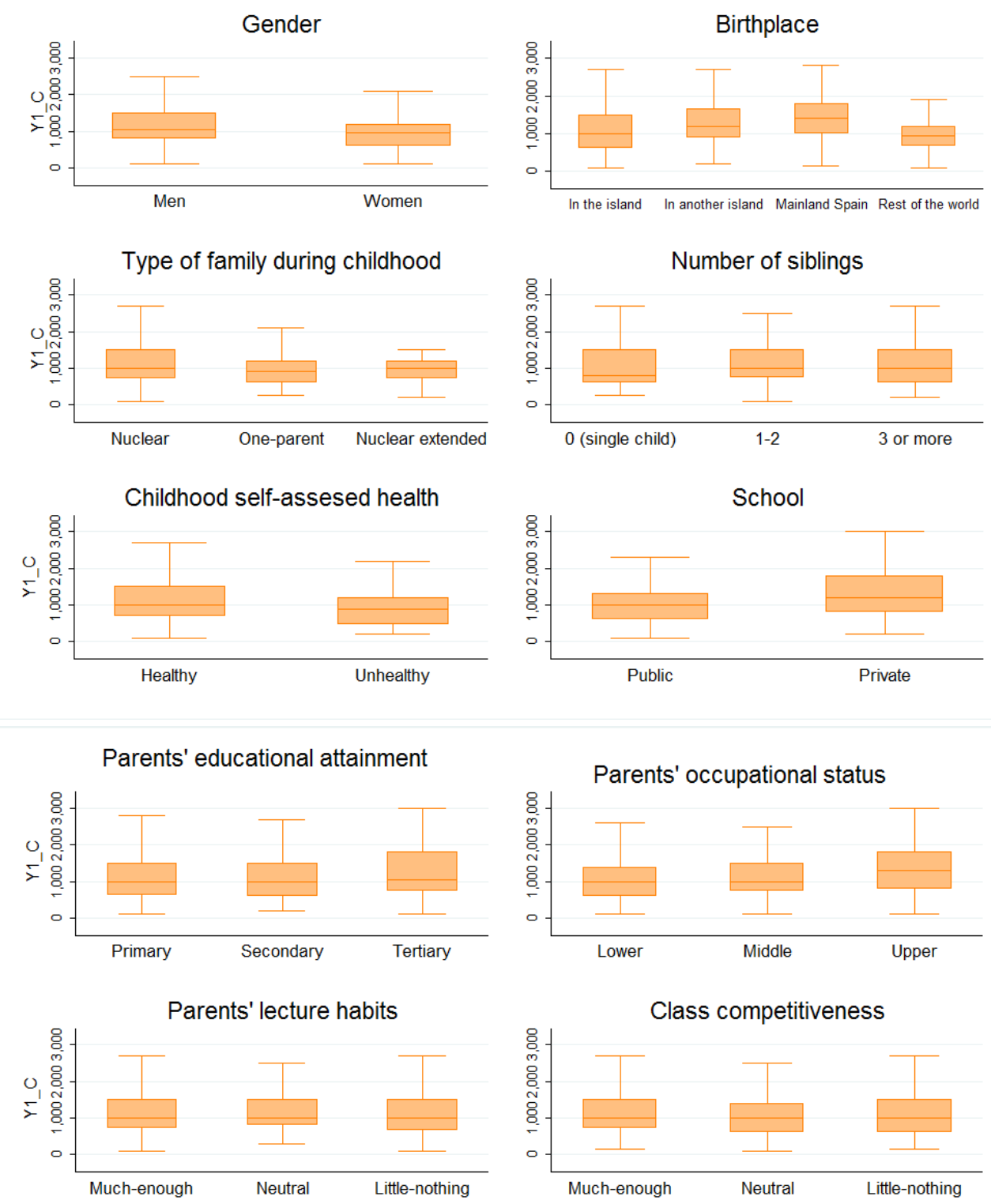

Family devoted resources on education
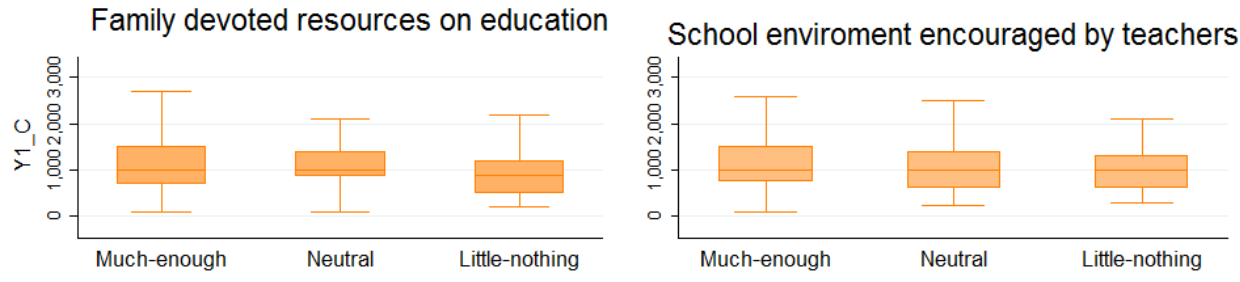

Figure 3: Circumstances' influence over net monthly personal income. 
To conclude this section, and with the aim of offering initial evidence of the importance of the different circumstances considered in this study, we provide a set of box plots (Figure 3) showing the income distribution for each group of individuals according to their circumstances. To save space, for the cases of parental education and occupation, only the highest levels of education and occupation are shown.

It is observed that men at the top part of the distribution obtain a net monthly income of almost $€ 500$ more than women, despite the average education level of men being lower than that of women. For instance, the presence of females in tertiary education is seven points higher than that of males: five points in the undergraduate education and two points more in postgraduate education. Place of birth also seems to play a relevant role when it comes to explaining individual income: average income of those born on the mainland is the highest, whereas that of foreigners is the lowest. Concerning the type of family during childhood, growing up in a single-parent family or two-parent extended family is to some extent associated with lower income levels. Whereas the number of siblings does not seem to be a relevant factor, being in good health during childhood is a relevant positive factor. Parental education level (especially having tertiary education), high occupational status, and having attended private schools are also associated with higher levels of income. Regarding the environment at home, the fact that the parents read or devoted resources to the education of their children is a significant variable for explaining the educational goals achieved (figure not shown), but it does not seem to have an effect on income. Lastly, the fact that the individual remembers that her classmates competed for grades at school and teachers encouraged a good study environment does not seem to have a significant effect on income either (see Marrero et al., 2017).

\section{Inequality and inequality of opportunity in the Canary Islands}

In this section, we estimate the IO for the whole of the Canary Islands and for certain relevant groups of islands. As one of the objectives was to study differences between relevant groups of islands, and in order to maintain adequate sample sizes, we distinguish among capital islands (Tenerife and Gran Canaria), peripheral eastern islands (Lanzarote and Fuerteventura), and peripheral western islands (La Palma, La Gomera and El Hierro). In addition, and as a preliminary analysis, we study migration flows between and among islands and toward the continent using official data from ISTAC (2000-2016), analysing whether these may be associated with the differences in IO observed between groups of islands.

Among the existing methods of estimating IO (Bourguignon et al., 2007; Lefranc et al., 2009; Li Donni et al., 2015; Pistolesi, 2009; Rodríguez, 2008; Roemer, 1998), we adopt the ex-ante parametric approach in Ferreira and Guignoux (2011) because it permits full comparability with previous results for Spain and Europe (Dunnzlaff et al., 2011; Marrero \& Rodriguez, 2012) and allows us to take full advantage of the high number of circumstances in our database. The analysis is based on the Mean Logarithmic Deviation (MLD), the only additively decomposable index whose decomposition is path-independent (Foster \& Shneyerov, 2000). Once people are grouped into groups according to their circumstances, total inequality is separated into IO (between-group inequality) and residual inequality (within-group inequality). The within-group inequality component contains non-observed circumstances, luck, and other measurement errors, which prevent us from considering this 
measure as a proxy for inequality due to individual effort. For illustrative purposes, we also include the Theil index $\left(\mathrm{T}_{1}\right)$, which belongs to the Generalized Entropy index class and is therefore additively separable (Bourguignon, 1979), and the Gini index, which despite not being additively decomposable, is the most used index to measure total inequality, and its between-group component can be considered as a proxy for IO (Brunori et al., 2016). See Ferreira and Guignoux (2011) and Marrero and Rodriguez (2012) for a technical description of the methodology.

\section{The set of circumstances and individual income}

The ex-ante parametric method is based on estimation of the following reduced form, which relates to the individuals' income and set of circumstances:

$$
\ln \left(y_{i}\right)=\lambda_{0}+\lambda_{1} C_{i}+\varepsilon_{i}
$$

where $i$ refers to an individual, $y_{i}$ corresponds to her income, $C_{i}$ refers to her circumstances, and $\varepsilon_{i}$ is a regression residual (the part of the income not explained by the observed circumstances). We use robust OLS to estimate (1) and consider four models according to different sets of circumstances. The first model considers four basic circumstances: gender, place of birth, type of household in which she grew up, and health status during childhood. The second model adds the type of school attended by the individual during adolescence (public or private) and both parental education and occupation. The third model includes, in addition to the first set of circumstances, those relating to the environment, both at home and at school during adolescence. Finally, the fourth model considers all circumstances simultaneously. The estimation results are shown in Table 2.

Regardless of the estimated model, being a woman implies a $17 \%$ to $20 \%$ lower income. In fact, IO by gender remains important despite the higher investment of women in education resources (see the previous section).

Regarding place of birth, both foreigners and people from the Canary Islands who have not left the island on which they were born tend to be worse off than those coming from the Spanish mainland or people from the Canary Islands who have left the island on which they were born. In this respect, note that, relative to their population, there is greater mobility from peripheral to capital islands than the other way. These migration flows are most likely related to the presence of greater opportunities on the capital islands than on the peripheral ones. This fact is analysed later in this section.

Our results show that being born and raised in a single-parent family is an unfavourable circumstance, with an individual earning on average between $10 \%$ and $14 \%$ less income than if she were born in a two-parent family. This circumstance may be influenced by the individual's socioeconomic context, but the family structure remains significant even after controlling for socioeconomic context. This result is consistent with Pérez et al. (2013) using a different survey and methodology. Note also that a wide range of studies conclude that nonintact families (one-parent families, deceased parents, living with relatives other than parents, etc.) run a higher risk of low achievement or academic failure (Amato, 2001; Biblarz \& Gottainer, 2000; Martínez García, 2008).

To conclude with the first set of circumstances, the individual's self-perceived health status during her adolescence is also a relevant variable for all estimated models: self-declaring that one was an unhealthy person at the age of 16 has a negative influence on the individual's 
future income (on average, between 13\% and 18\% less income, depending on the model estimated). This result is consistent with the literature on public health, which relates children's health to adult health status and the education level attained, social status, and income. The impact of unfavourable health during childhood and adolescence was brought to light by authors like Ravelli et al. (1998) and Marmot (2000, 2005). Children who experienced diverse deficiencies during the intrauterine stage and bad health during childhood achieved worse academic level and a low socioeconomic level during adulthood (Currie \& Goodman, 2010; Goodman et al., 2011). Even self-perception of the health level in adulthood seems to be directly related to bad health during childhood (Rosa Dias, 2009).

For Models 2 and 4, the category that is especially significant is that of parents belonging to the so-called 'upper class', which provides a $22 \%$ higher income than belonging to the 'lower class'. The high correlation between parental occupation and education (around 65\%) partly explains why both variables are not individually significant at the same time but are significant in tandem. For models 2 and 4 , the $p$-value of the test $F$ (joint significance) is below 0.05 . The lack of variability for the 'parental education' circumstance probably also reduces the significance of the education variable compared to that of 'parental occupation': $77.6 \%$ of individuals state that their parents have primary education $(9.9 \%$ secondary and $12.4 \%$ tertiary), compared to $49.1 \%$ belonging to lower class $35.1 \%$ to middle class and $15.7 \%$ to upper class. In any case, these results suggest that, from the two most popular channels of IO transmission, parental education and occupation (Palomino et al., 2018a, 2018b), the occupation channel is more relevant for the Canary Islands.

In contrast, type of school is one of the variables that turns out to be highly predictive for all the models in which it is included. In this sense, having attended a public school (compared to a private one) is an unfavourable circumstance, creating an average disadvantage of between $16 \%$ and $17 \%$ less income, depending on the model suggested. This result, having been tested very few times due to the lack of databases, is consistent with the existing literature, which finds that the educational performance of students in Spain (and in the Canary Islands) is better in private schools. In fact, the inequality of results depending on type of school is a common trend in OECD countries, even though the Canary Islands is the region in which this distance is the widest, according to the last PISA report (Ministerio de Educación, Cultura y Deporte, 2016).

Regarding the last set of circumstances, those related to perceptions about the environment at home and at school, we find that there are two individually significant variables according to Model 3, namely the value of effort being instilled both at home and at school. Note that the negative sign of the estimated coefficient shows that those cases in which the value of effort was hardly instilled or not at all instilled are unfavourable (as defined the circumstance in Table 1). Additionally, the fact that parents read regularly during adolescence and devoted resources to education are variables that favour income but are not individually significant. It is worth mentioning that these four variables are jointly significant in Model 3, but they all cease to be jointly and individually significant when, in Model 3, parental education and occupation as well as type of school are included (as in Model 4). This indicates that family environment (related to income) is highly correlated with parental socioeconomic and educational status. 
Table 2: Estimation results: Individual's income and circumstances.

Model specification

\begin{tabular}{|c|c|c|c|c|}
\hline Variable & (1) & $(2)$ & (3) & (4) \\
\hline Intercept $\left(\beta_{o}\right)$ & $\begin{array}{l}6.778 \star \star \star \\
(111.89)\end{array}$ & $\begin{array}{l}6.756 \star \star \star \\
(97.67)\end{array}$ & $\begin{array}{l}6.872 \star \star \star \\
(101.42)\end{array}$ & $\begin{array}{l}6.819 \star \star \star \\
(87.77)\end{array}$ \\
\hline Gender $_{i}$ ("Woman") & $\begin{array}{l}-0.174 \star \star \star \\
(-5.05)\end{array}$ & $\begin{array}{l}-0.203 \star \star \star \\
(-5.31)\end{array}$ & $\begin{array}{l}-0.180 \star \star \star \\
(-5.21)\end{array}$ & $\begin{array}{l}-0.202^{\star \star \star} \\
(-5.28)\end{array}$ \\
\hline $\begin{array}{l}\text { BirthPlace }_{i} \text { ("Canary Islands, } \\
\text { from a different island") }\end{array}$ & $\begin{array}{l}0.187 \star \star \star \\
(3.38)\end{array}$ & $\begin{array}{l}0.196^{\star \star \star} \\
(3.28)\end{array}$ & $\begin{array}{l}0.181 \star \star \star \\
(3.30)\end{array}$ & $\begin{array}{l}0.195 \star \star \star \\
(3.27)\end{array}$ \\
\hline $\begin{array}{l}\text { BirthPlace }_{i} \quad \text { ("Mainland } \\
\text { Spain") }\end{array}$ & $\begin{array}{l}0.274 \star \star \star \\
(4.94)\end{array}$ & $\begin{array}{l}0.245^{\star \star \star} \\
(3.97)\end{array}$ & $\begin{array}{l}0.277 \star \star \star \\
(4.95)\end{array}$ & $\begin{array}{l}0.245^{\star \star \star} \\
(3.95)\end{array}$ \\
\hline $\begin{array}{l}\text { BirthPlace }_{i} \text { ("Rest of the } \\
\text { World") }\end{array}$ & $\begin{array}{l}-0.0510 \\
(-0.88)\end{array}$ & $\begin{array}{l}-0.117 \\
(-1.64)\end{array}$ & $\begin{array}{l}-0.0632 \\
(-1.08)\end{array}$ & $\begin{array}{l}-0.121^{\star} \\
(-1.67)\end{array}$ \\
\hline Home $_{i}$ ("Single-parent home”) & $\begin{array}{l}-0.146^{\star \star \star} \\
(-2.90)\end{array}$ & $\begin{array}{l}-0.115^{\star} \\
(-1.93)\end{array}$ & $\begin{array}{l}-0.122^{\star \star} \\
(-2.40)\end{array}$ & $\begin{array}{l}-0.105^{\star} \\
(-1.74)\end{array}$ \\
\hline $\begin{array}{l}H_{o m e} \text { ("Extended nuclear } \\
\text { home") }\end{array}$ & $\begin{array}{l}-0.114 \\
(-0.98)\end{array}$ & $\begin{array}{l}-0.0713 \\
(-0.55)\end{array}$ & $\begin{array}{l}-0.103 \\
(-0.86)\end{array}$ & $\begin{array}{l}-0.0729 \\
(-0.57)\end{array}$ \\
\hline $\begin{array}{l}\text { ChildhoodHealth } \\
\text { ("Healthy") }\end{array}$ & $\begin{array}{l}0.186^{\star \star \star} \\
(3.26)\end{array}$ & $\begin{array}{l}0.146 \star \star \\
(2.30)\end{array}$ & $\begin{array}{l}0.173 \star \star \star \\
(2.97)\end{array}$ & $\begin{array}{l}0.132 \star \star \\
(2.05)\end{array}$ \\
\hline $\begin{array}{l}\text { PSReadingHabits }_{i} \text { (“A bit - } \\
\text { Never") }\end{array}$ & & & $\begin{array}{l}-0.0387 \\
(-1.10)\end{array}$ & $\begin{array}{l}0.00917 \\
(0.22)\end{array}$ \\
\hline $\begin{array}{llll}\text { PEffCulture }_{i} & \text { ("A } & \text { bit } & \text { - } \\
\text { Nothing") } & & & \\
\end{array}$ & & & $\begin{array}{l}-0.185^{\star \star} \\
(-2.14)\end{array}$ & $\begin{array}{l}-0.0994 \\
(-1.04)\end{array}$ \\
\hline $\begin{array}{l}\text { PEdResources }_{i} \text { ("Few - No } \\
\text { resources") }\end{array}$ & & & $\begin{array}{l}-0.0531 \\
(-1.16)\end{array}$ & $\begin{array}{l}-0.0235 \\
(-0.45)\end{array}$ \\
\hline $\begin{array}{llll}\text { StudyEnv }_{i} & \text { ("A } & \text { bit } & - \\
\text { Nothing") } & & & \end{array}$ & & & $\begin{array}{l}-0.0628^{\star} \\
(-1.67)\end{array}$ & $\begin{array}{l}-0.0596 \\
(-1.42)\end{array}$ \\
\hline School $_{i}$ ("Private") & & $\begin{array}{l}0.168^{\star \star \star} \\
(3.17)\end{array}$ & & $\begin{array}{l}0.162^{\star \star \star} \\
(3.00)\end{array}$ \\
\hline PEducation $_{i}$ (“Secondary”) & & $\begin{array}{l}-0.0428 \\
(-0.68)\end{array}$ & & $\begin{array}{l}-0.0334 \\
(-0.52)\end{array}$ \\
\hline PEducation $_{i}$ ("Tertiary”) & & $\begin{array}{l}-0.0273 \\
(-0.28)\end{array}$ & & $\begin{array}{l}-0.0388 \\
(-0.39)\end{array}$ \\
\hline PSocialClass $_{i}$ (“Middle class") & & $\begin{array}{l}0.0297 \\
(0.69)\end{array}$ & & $\begin{array}{l}0.0186 \\
(0.41)\end{array}$ \\
\hline PSocialClass $_{i}$ (“Upper class”) & & $\begin{array}{l}0.223 \star \star \\
(2.53)\end{array}$ & & $\begin{array}{l}0.223 \star \star \\
(2.47)\end{array}$ \\
\hline Number of observations (N) & 1,145 & 934 & 1,133 & 927 \\
\hline Adjusted $\mathrm{R}^{2}$ & 0.063 & 0.099 & 0.069 & 0.098 \\
\hline
\end{tabular}

Inequality of Opportunity results and discussion

The estimated OLS coefficients $\hat{\lambda}_{1}$ and $\hat{\lambda}_{2}$ are used to obtain the 'smoothed income distribution' in which all individuals belonging to the same type are assigned the same income. 
Then, IO is computed by applying a given inequality index to the smoothed income distribution. In this manner, IO represents the part of total inequality explained by differences in individual circumstances-inequality between types.

In Table 3, we show the estimate of total inequality and the IO ratio (IO with respect to total inequality) in the Canary Islands for the four models considered. It is impossible to observe all individuals' circumstances so the IO estimates are actually a lower bound (Ferreira \& Gignoux, 2011).

Table 3: Total inequality and IO ratio in the Canary Islands archipelago.

Model specification

\begin{tabular}{lllll} 
Estimate & $(1)$ & $(2)$ & $(3)$ & $(4)$ \\
\hline MLD-index & 16.91 & 17.53 & 16.91 & 17.53 \\
IO ratio (MLD) & 7.36 & 12.10 & 8.26 & 12.39 \\
\hline Theil 1-index & 16.17 & 16.85 & 16.17 & 16.85 \\
IO ratio (Theil1) & 7.78 & 12.90 & 8.66 & 13.21 \\
\hline Gini & 30.71 & 31.19 & 30.71 & 31.19 \\
IO ratio (Gini) & 28.05 & 37.16 & 30.44 & 37.80 \\
\hline
\end{tabular}

Focusing on the MLD, IO in the Canary Islands represents $12.4 \%$ of total inequality, while the Theil 1 and Gini indices are 13.2\% and 37.8\%, respectively (Model 4). Consistent with Brunori et al. (2016), the MLD (and Theil 1) is notably lower than the Gini index. Taking as a reference the estimates of European and Latin American countries using the same procedure (Ferreira \& Gignoux, 2011; Marrero \& Rodríguez, 2012), the MLD IO ratio found for the Canary Islands archipelago is similar to the value of Spain and countries such as Ireland and France but higher than those of the Northern Countries and Central Europe (with the exception of Belgium), and lower than those of Latin American countries, which reach 20\% on average. When comparing the models, it is worth noting that the first and second set of circumstances are the most important for explaining IO, while the third set of circumstances (related to home and school environment) contributes very little to the estimated IO ratios.

Next, we compare total inequality and IO for the whole of the Canary Islands and for the different groups of islands (capital, western peripheral, and eastern peripheral islands) in Table 4. Comparing these groups is useful, but it also allows us to have reasonable sample sizes for obtaining accurate estimates of IO. Thus, we estimate the same equation (1) for each group of islands and we carry out the same procedure to calculate IO. To save space, we only show results for Model 1 (including only basic circumstances) and Model 4 (including all circumstances).

Total inequality is generally lower for the group of peripheral islands (especially for the eastern peripheral islands) than for capital islands. However, IO ratio is higher in the peripheral islands than in the capital islands. Thus, the capital islands show an MLD of 17.9\% (Model 1) and $18.5 \%$ (Model 4), while the IO ratios are similar to those for the whole of the Canary Islands (6.4\% for Model 1 and 13.1\% for Model 4). In contrast, the groups of peripheral islands (eastern and western) show an MLD between $14.5 \%$ and 16.4\%. For Model 4, the IO ratios are 19.3\% for western and $20.8 \%$ for eastern peripheral islands. These IO ratio values resemble more the values of Latin American countries, whereas values of capital islands resemble more the values of European countries. 
Table 4: Total inequality and IO ratio by group of islands.

Model 1

\begin{tabular}{llll} 
Estimate & Capitals & $\begin{array}{l}\text { Peripheral } \\
(\text { Eastern })\end{array}$ & Peripheral (Western) \\
\hline MLD-index & 17.89 & 14.51 & 16.41 \\
IO ratio & 6.39 & 12.64 & 10.98 \\
\hline Theil 1 & 18.11 & 12.81 & 14.51 \\
IO ratio & 6.47 & 14.07 & 12.13 \\
\hline Gini & 31.90 & 27.84 & 29.88 \\
IO ratio & 24.88 & 38.39 & 31.93 \\
\hline
\end{tabular}

Model 4

\begin{tabular}{llll} 
Estimate & Capitals & $\begin{array}{l}\text { Peripheral } \\
(\text { Eastern})\end{array}$ & Peripheral (Western) \\
\hline LMD-index & 18.47 & 15.88 & 16.36 \\
IO ratio & 13.05 & 20.76 & 19.26 \\
\hline Theil1-index & 18.70 & 13.95 & 14.45 \\
IO ratio & 13.40 & 23.85 & 21.17 \\
\hline Gini & 32.27 & 29.11 & 29.83 \\
IO ratio & 38.22 & 49.62 & 46.11 \\
\hline
\end{tabular}

Although we should interpret these results with caution, we believe that the comparison is worthwhile due to its possible implications. Our results suggest that the importance of individual circumstances in the determination of IO increases clearly with an island's degree of isolation. At the same time, these results imply that the residual inequality component (a possible proxy for inequality of effort) is more relevant in the capital islands than in the more peripheral ones. Hence, the richest and less isolated islands have a lower IO ratio, and possibly present higher levels of effort inequality. A greater productive diversity; higher rates of employment, connectivity, and competence in key sectors like tourism; and higher size and diversity of demand in capital islands compared to peripheral islands could be behind these results. These aspects can negatively affect the efficiency of local institutions in peripheral islands with respect to capital islands, which might reduce meritocracy and increase nepotism in the former relative to the latter (Gjinovci, 2016).

One feasible explanation for why the peripheral islands have a higher IO relative to total inequality than the capital islands is related to the wider spectrum of available occupations in the capital islands than the peripheral islands. Using the latest available information from the Canary Institute of Statistics (Instituto Canario de Estadística, 2018b)), we find several noteworthy differences in the occupational structures of the different sets of islands. For example, while about the $23.3 \%$ (on average) of the workforce in the capital islands are general managers, managers, or scientists, only $13.3 \%$ and $16 \%$ belong to this category in the eastern and western peripheral islands respectively. Almost $40 \%$ of the labour force is concentrated in sectors related to tourism in the eastern islands, while almost $23 \%$ is concentrated in lowskilled jobs in the western islands. Another notable difference is found in the percentage of 
salaried public-sector workers: almost $36 \%$ in the western islands, $20 \%$ in the capitals, and slightly more than $15 \%$ in the eastern peripheries (due especially to the greater weight of the tourism sector in the latter). In addition, this structure makes a notable difference between the peripherals of the west and the east. Finally, and with respect to the level of education in the different sets of islands, which is also an important channel of inequality of opportunity (Palomino et al., 2018a, 2018b), it is worth noting that while almost 9\% (on average) of the population have tertiary education in the capital islands, this percentage is around $6 \%$ in the peripheral islands.

These differences in IO may be reflected in the migration flows from the more isolated islands to the capital islands (see Chetty et al., 2014, for the US). To illustrate this statement, we have compiled data on interior migration flows among islands (from ISTAC) and also migration flows from the Canary Islands to the mainland and out of Spain. Data is presented in percentages with respect to the population of origin. In this line of inquiry, Randall et al. (2014), for the case Prince Edward Island in Canada, relates the migration flow of islanders with the quality-of-life, which is related with better opportunities.

The evolution in the percentage of population that has moved (through change of residence) from one place to another between 2000 and 2016 is shown in Figure 4. The two upper charts are for the two groups of peripheral islands (eastern on the left and western on the right), and the lower one is for the capital islands. We show four lines in each chart: movements toward peripheral islands, toward capital islands, and, for illustrative purposes, also toward the mainland and abroad.

The majority of movements (in percentage) take place from peripheral islands to capital islands and to the mainland as well as from capital islands to the mainland. When peripheral islands are the source, their inhabitants move much more often toward capital islands than toward other peripheral islands (relative to population size, over five times more often for western islands and four times more often for eastern islands).

Migration from Eastern Islands to Mainland seems particularly high. A feasible explanation for that is related with the labour structure (this issue is commented on below). For instance, the eastern peripheral islands are the ones with the lowest percentage of wage earners working in the public sector: on average, $15.4 \%$, while in the western peripheries the percentage rises to $35.8 \%$ and to $20.4 \%$ in the capital islands. Also, there is a greater concentration of labour force in the tourism sector, which is much more subject to a more global mobility than in other sectors.

Moreover, mobility percentages toward capital islands resemble the movements toward the mainland and are clearly higher than movements to other countries. Finally, when we look at the inhabitants of the capital islands, we observe that the percentage of population moving to peripheral islands is very low $(0.25 \%)$, and it basically takes place toward Lanzarote and Fuerteventura, probably due to the tourist boom in those islands in recent years. The majority of movements from the capital islands are headed for the mainland and abroad (in 2016, about $1.15 \%$ and $0.40 \%$, respectively), probably because of the greater relative opportunities offered by these destinations. 


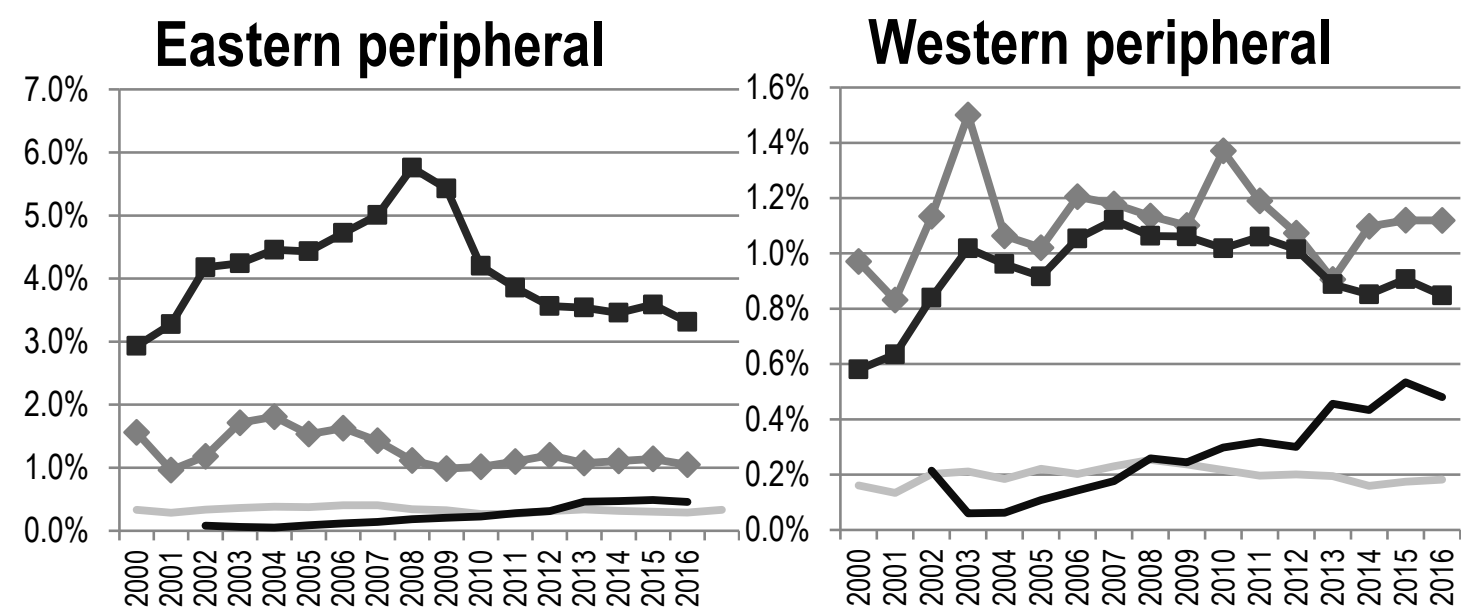

Capital islands

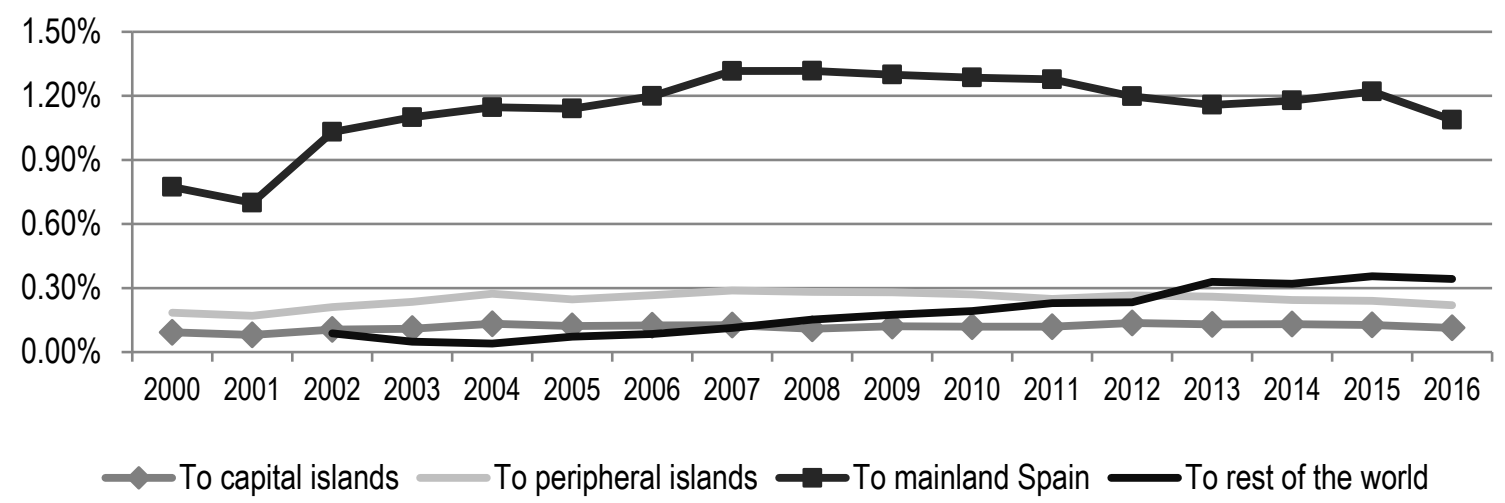

SOURCE: Own elaboration from statistics of residential variations (EVR) and census figures (ISTAC).

Figure 4: Migrant flows, by group of islands.

\section{Conclusions}

This article has estimated the inequality of opportunity (IO) for the Canary Islands archipelago, a European outermost region of seven islands, including two capital islands and five peripheral islands.

For this task, we have designed a survey which includes a wide set of circumstances, such as gender, place of birth, structure of household where the individual grew up and health perception during adolescence, the type of school (public/private), the education level and occupational status of their parents, and a set of circumstances relating to family and school environment during adolescence.

For all of the Canary Islands, IO represents approximately $12.4 \%$ of total inequality, which is in line with the values found for South European countries in related studies. However, when we distinguish between capital islands and eastern and western peripheral islands, we find that the former shows an IO ratio similar to that of Southern Europe in general while the IO ratio of the latter is almost $20 \%$ of total inequality, which is more in line with some Latin American economies. 
These differences may be, at least in part, at the origin of significant migration flows from peripheral islands to capital islands and could cause future divergence in the development of capital and peripheral islands. Despite our initial reflections here, understanding the connection between IO and migration flows between islands remains a clear research challenge for the future.

\section{Acknowledgements}

We greatly acknowledge the comments from the editor and one referee. We thank the financial support from Fundación Caja Canarias (Spain). Marrero and Darias-Curvo also acknowledge Gobierno de Canarias for support through the R\&D project ProID2017010088 (María del Carmen Betancourt y Molina program), co-funded by the Operative Program FEDER 2014-2020. All views, and any errors or omissions are our own responsibility.

\section{References}

Amato, P.R. (2001). Children of divorce in the 1990s: An update of the Amato and Keith (1991) meta-analysis. Journal of Family Psychology, 15(3), 355-370. https://doi.org/10.1037/0893-3200.15.3.355

Armstrong, H.W, Giordano, B., Kizos, T., Macleod, C., Olsen, L.S., \& Spilanis, I. (2012). The European Regional Development Fund and island regions: An evaluation of the 2000-06 and 2007-13 programs. Island Studies Journal, 7(2), 177-198.

Ayala Cañón, L. (2016). La Desigualdad En España: Fuentes, Tendencias y Comparaciones Internacionales. Madrid: FEDEA.

Biblarz, T., \& Gottainer, G. (2000). Family structure and children's success: A comparison of widowed and divorced single-mother families. Journal of Marriage and the Family, 62(2), 533-548. https://doi.org/10.1111/j.1741-3737.2000.00533.x

Bourguignon, F. (1979). Descomposable income inequality measures. Econometrica, 47, 901920. https://doi.org/10.2307/1914138

Bourguignon, F., F. Ferreira, and M. Menéndez (2007). Inequality of Opportunity in Brazil, Review of Income and Wealth, 53, 585-618.

Bradbury, K., \& Triest, R. (2016). Inequality of opportunity and aggregate economic performance. Russel Sage Foundation Journal of the Social Sciences, 2, 178-201. https://doi.org/10.7758/rsf.2016.2.2.08

Brunori, P., Peragine, V., \& Serlenga, L. (2016). Upward and downward bias when measuring inequality of opportunity. ECINEQ Working Paper 2016-406. https://doi.org/10.2139/ssrn.2839232

Chetty, R., Hendren, N., Kline, P., \& Saez, E. (2014). Where is the land of opportunity? The geography of intergenerational mobility in the United States. The Quarterly Journal of Economics, 129(4), 1553-1623. https://doi.org/10.1093/qje/qju022

Currie, J., \& Goodman, J. (2010). Parental socioeconomic status, child health, and human capital. In P. Peterson, E. Baker, \& B. McGaw (Eds) International encyclopaedia of education (pp. 253-259). Elsevier. https://doi.org/10.1016/B978-0-08-044894-7.01268-9 
Dunnzlaff, L., Neumann, D., Niehues, J., \& Peichl, A. (2011). Equality of opportunity and redistribution in Europe. Research on Economic Inequality (19), 99-129. https://doi.org/10.1108/S1049-2585(2011)0000019008

European Commission (2018). Regional policy \& outermost regions. European Commission. http://ec.europa.eu/regional policy/en/policy/themes/outermost-regions/

Ferreira, F., \& Gignoux, J. (2011). The measurement of inequality of inequality of opportunity: theory and an application to Latin America. The Review of Income and Wealth, 57(4), 622-657. https://doi.org/10.1111/j.1475-4991.2011.00467.x

Fleurbaey, M. (2008). Fairness, responsibility, and welfare. Oxford: Oxford University Press. https://doi.org/10.1093/acprof:osobl/9780199215911.001.0001

Foster, J., \& Shneyerov, A. (2000). Path independent inequality measures. Journal of Economic Theory, 91, 199-222. https://doi.org/10.1006/jeth.1999.2565

Goodman, A., Joyce, R., \& Smith, J.P. (2011). The long shadow cast by childhood physical and mental problems on adult life. Proceedings of the National Academy of Sciences, 108 (15), 6032-6037. https://doi.org/10.1073/pnas.1016970108

Instituto Canario de Estadística (2018a). PIB. Indicadores según comunidades autónomas y años (Base 2010). Contabilidad Regional de España / Series anuales del PIB y sus componentes según el enfoque funcional. Instituto Canario de Estadística.

Instituto Canario de Estadística (2018b). Variaciones residenciales según sexos, grupos de edad y tipos de variaciones. Estadística de Variaciones Residenciales. Series anuales. Municipios de Canarias. 1988-2016. Instituto Canario de Estadística.

Instituto Nacional de Estadística (2017a). Resultados nacionales. Riesgo de pobreza (renta año anterior a la entrevista). Coeficiente de Gini. Instituto Nacional de Estadística.

Instituto Nacional de Estadística. (2017b). Riesgo de pobreza y/o exclusión social (estrategia Europa 2020). Indicador AROPE. Instituto Nacional de Estadística.

Gjinovci, A. (2016). The impact of nepotism and corruption in economy and HR. Economic and Environmental Studies, 116(3), 421-434.

Lefranc, A., N. Pistolesi, and A. Trannoy (2009). Equality of Opportunity and Luck: Definitions and Testable Conditions, with an Application to Income in France, Journal of Public Economics, 93, 1189-207.

Li Donni, P., Rodríguez, J.G., \& Rosa-Dias, P. (2015). Empirical definition of social types in the analysis of inequality of opportunity: A latent class approach. Social Choice and Welfare, 44, 673-701. https://doi.org/10.1007/s00355-014-0851-6

Marmot, M. (2000). Multilevel approaches to understanding social determinants. In L.F.K. Berkman (Ed.) Social Epidemiology (pp. 349-367). New York: Oxford University Press.

Marmot, M. (2005). Status syndrome: how social standing affects our health and longevity. New York: Owl.

Marrero, G.A., Betancort Montesinos, M., Cabrera Rodríguez, L.J., Darias Curvo, S., Pérez Sánchez, C.N., Rodríguez Hernández, J.G., \& Sánchez Rodríguez, D. (2017). Desigualdad de oportunidades y movilidad intergeneracional en Canarias. Santa Cruz de Tenerife: Fundación Cajacanarias. https://doi.org/10.25145/r.cedesog.2018.002

Marrero, G.A., \& Ramos-Real, F.J. (2010). Electricity generation cost in isolated system: the complementarities of natural gas and renewables in the Canary Islands. Renewable and Sustainable Energy Reviews, 14(1), 2808-2818. https://doi.org/10.1016/j.rser.2010.06.007 
Marrero, G.A., \& Rodríguez, J.G. (2012). Inequality of opportunity in Europe. Review of Income and Wealth, 58, 597-621. https://doi.org/10.1111/j.1475-4991.2012.00496.x

Marrero, G.A., \& Rodríguez, J.G. (2013). Inequality of opportunity and growth. Journal of Development Economics, 104, 107-122.

Marrero, G.A., Rodríguez, J.G., \& van der Weide, R. (2016). Unequal opportunity, unequal growth. World Bank Policy Research Working Paper Series 7853. https://doi.org/10.1596/1813-9450-7853

Martínez García, J.S. (2008). Clase social, tipo de familia y logro educativo en Canarias. $\begin{array}{llll}\text { PAPERS. Revista } & \text { Sociología, 77-100. }\end{array}$ https://doi.org/10.5565/rev/papers/v87n0.790

Ministerio de Educación, Cultura y Deporte. (2016). PISA 2015. Programa para la Evaluación Internacional de los Alumnos. Informe espa-ol. Secretaría de Estado de Educación, Formación Profesional y Universidades, Instituto Nacional de Evaluación Educativa, Madrid.

Palomino, J.C., Marrero, G.A., \& Rodríguez, J. G. (2018a). One size doesn't fit all: A quantile analysis of intergenerational income mobility in the US (1980-2010). Journal of Economic Inequality, 16(3), 347-368. https://doi.org/10.1007/s10888-017-9372-8

Palomino, J.C., Marrero, G.A., Rodríguez, J.G. (2018b). Channels of inequality of opportunity: The role of education and occupation in Europe. Social Indicators Research, https://doi.org/10.1007/s11205-018-2008-y

Pérez, C. N., Betancort, M., \& Cabrera, L. (2013). Family influences in academic achievement: A study of the Canary Islands. Revista Internacional de Sociología, 71(1), 169-187. https://doi.org/10.3989/ris.2011.04.11

Pistolesi, N. (2009). Inequality of Opportunity in the land of Opportunities, 1968-2001, Journal of Economic Inequality, 7, 411-433.

Ramos, X., \& Van de Gaer, D. (2017). Is inequality of opportunity robust to the measurement approach? ECINEQ Working Papers 450, Society for the Study of Economic Inequality (ECINEQ).

Randall, J.E., Kitchen, P., Muhajarine, N., Newbold, B., Williams, A., \& Wilson, K. (2014). Immigrants, islandness and perceptions of quality-of-life on Prince Edward Island, Canada. Island Studies Journal, 9(2), 343-362.

Ravelli, A.C., van der Meulen, J.H., Michels, R.P., Osmond, C., Barker, D.J., Hales, C. N., \& Bleker, O.P. (1998). Glucose tolerance in adults after prenatal exposure to famine. The Lancet, 351(9097), 173-177. https://doi.org/10.1016/S0140-6736(97)07244-9

Rodríguez, J.G. (2008). Partial equality-of-opportunity orderings. Social Choice and Welfare, 31(3), 435-456, https://doi.org/10.1007/s00355-007-0290-8

Rodriguez-Pose, A., \& Garcilazo, E (2015). Quality of government and the returns of investment: examining the impact of cohesion expenditure in European Regions. Regional Studies, 49(8), 1274-1290, https://doi.org/10.1080/00343404.2015.1007933

Roemer, J.E. (1993). A pragmatic approach to responsibility for the egalitarian planner. Philosophy \& Public Affairs, 10, 146-166.

Roemer, J.E. (1998). Equality or opportunity. Cambridge: Harvard University Press.

Roemer, J.E., \& Trannoy, A. (2016). Equality of opportunity: theory and measurement. Journal of Economic Literature, 54(4), 1288-1332. https://doi.org/10.1257/jel.20151206 
Moises Betancort et al.

Rosa Dias, P. (2009). Inequality of opportunity in health: Evidence from a UK cohort study. Health Economics, 18(9), 1057-1074, https://doi.org/10.1002/hec.1535

UNESCO. (2012). International Standard Classification of Education: ISCED 2011. Montreal: UNESCO Institute of https://uis.unesco.org/sites/default/files/documents/international-standardclassification-of-education-isced-2011-en.pdf 